\title{
Invasive serogroup W Neisseria meningitidis (MenW) in Ontario, Canada shows potential clonal replacement during the period January 1, 2009 - June 30, 2016
}

\author{
Tsang RSW ${ }^{1 *}$, Deeks $\mathrm{SL}^{2,3}$, Wong $\mathrm{K}^{2}$, Marchand-Austin $\mathrm{A}^{2}$, Jamieson FB ${ }^{2,3 *}$
}

\section{Abstract}

Background: In Ontario, serogroup W Neisseria meningitidis (MenW) accounts for a small percentage of all invasive meningococcal disease (IMD) and between 2010 and 2014, only zero to three confirmed cases occurred per year. However, between August 2015 and June 2016, six culture confirmed MenW IMD cases were reported in Ontario.

Objective: All MenW IMD cases in Ontario between January 1, 2009 and June 30, 2016 were reviewed and the $N$. meningitidis strains involved were characterized.

Methods: MenW cases were identified in the Integrated Public Health Information System by Public Health Ontario. MenW isolates were characterized at the National Microbiology Laboratory.

Results: Of the thirteen MenW IMD cases, six were due to isolates typed as sequence type (ST)-22 clonal complex (cc), six were of ST-11 cc, and one ST-167 cc. Most (83\%) MenW cases due to the ST-22 cc occurred prior to 2012 while all six MenW cases due to ST-11 cc happened since May 2014. The six MenW ST-11 isolates appeared to be clonal.

Conclusion: It appears that a genetic shift in the invasive MenW isolates has occurred in Ontario in 2014 with the ST-11 clone replacing the traditional ST-22 clone.

\author{
Affiliations \\ ${ }^{1}$ National Microbiology \\ Laboratory, Public Health Agency \\ of Canada, Winnipeg, MB \\ 2 Public Health Ontario, Toronto, \\ ON \\ ${ }^{3}$ University of Toronto, Toronto, \\ ON
}

*Correspondence: raymond. tsang@phac-aspc.gc.ca, frances. jamieson@oahpp.ca

Suggested citation: Tsang RSW, Deeks SL, Wong K, Marchand-Austin A, Jamieson FB. Invasive serogroup W Neisseria meningitidis (MenW) in Ontario, Canada shows potential clonal replacement during the period January 1, 2009 to June 30, 2016. Can Comm Dis Rep 2016;42(12):263-6. https://doi.org/10.14745/ ccdr.v42i12a06

\section{Introduction}

Invasive meningococcal disease (IMD) is caused by the strict human pathogen Neisseria meningitidis, which may cause severe invasive disease in susceptible individuals including meningitis, septicemia, bacteremic pneumonia, septic arthritis or pericarditis. Almost all invasive isolates of $N$. meningitidis are encapsulated, and the capsule is the basis of the serogrouping antigen and the protective vaccine for serogroups $A, C, W$ (or formerly W135), and $Y(1)$. Currently 12 different serogroups of meningococci are recognized but most infections are caused by serogroups $A, B, C, W, X$ and $Y(2,3)$.

According to historical data, serogroup A N. meningitidis (MenA) was the most commonly isolated meningococci in Canada in 1971 and 1972 (4). Since then, the prevalence of MenA has declined and by the mid-1990s, MenA only accounted for $1 \%$ or less of the IMD cases in Canada (5). Now, MenA is no longer endemic in Canada. Currently, most IMD cases are caused by serogroup $B(M e n B)$ and serogroup $Y(M e n Y)(6)$, especially after MenC conjugate vaccine was incorporated into publicly-funded childhood immunization programs across the country in the early to mid-2000s (7). In Ontario, MenC conjugate vaccine was introduced at 12 months of age and for grade seven students in 2004/05. In 2009, quadrivalent meningococcal conjugate vaccine $(A, C, Y, W)$ replaced MenC vaccine for grade seven students.

From 2006 to 2011, serogroup W (MenW) N. meningitidis accounted for only $5.7 \%$ (62 out of 1,092 isolates) of all invasive meningococci isolated in Canada (6). In the province of Ontario, between 2010 and 2014, there were only zero to three culture confirmed MenW IMD cases per year. However, between August 2015 and June 2016, six culture confirmed MenW IMD cases were reported; five appeared to be due to the same strain typed as $\mathrm{W}: 2 \mathrm{a}: \mathrm{P1}$.2,(5) sequence type (ST)-11. The objective of this study was to review all MenW IMD case isolates received at the National Microbiology Laboratory (NML) from the province of Ontario between January 1, 2009 and June 30, 2016.

\section{Materials and methods}

IMD is a reportable disease in Ontario and data regarding cases are captured in the provincial reportable disease database and 
the Integrated Public Health Information System (iPHIS) (8). The Public Health Ontario (PHO) laboratory routinely receives all IMD case isolates through its regional laboratories and/or community hospitals. Isolates received were confirmed as $N$. meningitidis using standard biochemical tests and serogrouped using bacterial agglutination method and antisera provided by the NML. Isolates were also forwarded to the NML for serotyping, serosubtyping, PorA genotyping and multi-locus sequence typing (MLST) (9). Isolates in the electrophoretic type (ET)-37 or ST-11 clonal complex (cc) were further subdivided into the ET-15 and the ET-37 (not ET-15) types by extending the DNA sequencing of their fum $C$ genes to identify the molecular signatures for differentiating these ET types (10).

This study included MenW isolates received from Ontario at the NML between January 1, 2009 and June 30, 2016. The list of isolates was verified by $\mathrm{PHO}$ against cases reported to iPHIS during the same time period to ensure completeness. Age and sex of the cases were obtained from the specimen requisition forms.

\section{Results}

Thirteen MenW IMD case isolates from the province of Ontario were identified between January 1, 2009 and June 30, 2016 (Table 1). The 13 individuals included six females and seven males between 15 months and 86 years of age, with a median age of 53.4 years. The majority of cases were adults (77\%), and of these, most were older adults. Only three cases occurred in children and all were two years of age and younger. None of the 13 cases had a fatal outcome. Blood culture was the most common specimen source (85\%). Six of the cases occurred during the winter months of December to March while the rest occurred from April to September. As these cases were caused

\section{Table 1: Microbiological characteristics of invasive serogroup W Neisseria meningitidis isolated in the province of Ontario from invasive meningococcal disease cases between the period January 1, 2009 and June 30, 2016}

\begin{tabular}{|c|c|c|c|c|c|c|c|}
\hline $\begin{array}{c}\text { Case } \\
\text { No. }\end{array}$ & Age/sex & $\begin{array}{c}\text { Specimen } \\
\text { source }\end{array}$ & $\begin{array}{c}\text { Culture } \\
\text { isolation } \\
\text { date }\end{array}$ & $\begin{array}{c}\text { Culture's } \\
\text { Antigenic } \\
\text { formula }\end{array}$ & $\begin{array}{c}\text { PorA } \\
\text { genotype }\end{array}$ & MLST ST & $\begin{array}{c}\text { Clonal } \\
\text { complex }\end{array}$ \\
\hline 11 & $86 / F$ & $\begin{array}{c}\text { shoulder } \\
\text { fluid }\end{array}$ & Dec. 2008 & W:NT:P1.6 & P1.18-1,3,38 & ST-22 & ST-22 \\
\hline 2 & $2 / F$ & CSF & Feb. 2009 & W:NT:P1.6 & P1.18-1,3,38 & ST-8230 & ST-22 \\
\hline 3 & $\begin{array}{c}15 \\
\text { months/F }\end{array}$ & Blood & May 2010 & W:NT:P1.- & P1.18-1,3,38 & ST-8974 & ST-22 \\
\hline 4 & $82 / F$ & Blood & Feb. 2011 & W:NT:P1.- & P1.19,15,36 & ST-22 & ST-22 \\
\hline $5^{2}$ & $1 / \mathrm{M}$ & Blood & April 2011 & W:NT:P1.- & $\begin{array}{c}\text { porA gene } \\
\text { deletion }\end{array}$ & ST-184 & ST-22 \\
\hline 6 & $78 / \mathrm{M}$ & Blood & Mar. 2011 & W:19:P1.5 & P1.5-1,10-4,36-2 & ST-3705 & ST-167 \\
\hline 7 & $53 / F$ & Blood & May 2014 & W:2a:P1.5,2 & P1.5,2,36-2 & ST-10826 & ST-10826 \\
\hline 8 & $53 / F$ & Blood & Aug. 2015 & W:2a:P1.5,2 & P1.5,2,36-2 & ST-11 & ST-11 \\
\hline 9 & $66 / M$ & Blood & Sept. 2015 & W:2a:P1.5,2 & P1.5,2,36-2 & ST-11 & ST-11 \\
\hline 10 & $36 / M$ & Blood & Dec. 2015 & W:NT:P1.16 & P1.18-1,16,37-1 & ST-184 & ST-22 \\
\hline 11 & $60 / M$ & Blood & Mar. 2016 & W:2a:P1.2 & P1.5,2,36-2 & ST-11 & ST-11 \\
\hline 12 & $83 / M$ & Blood & June 2016 & W:2a:P1.2 & P1.5,2,36-2 & ST-11 & ST-11 \\
\hline 13 & $27 / M$ & Blood & June 2016 & W:2a:P1.2 & P1.5,2,36-2 & ST-11 & ST-11 \\
\hline
\end{tabular}

Abbreviations: PorA, class 1 outer membrane protein (P1.) variable regions 1,2, and 3 (denoted by numbers separated by commas); MLST, multi-locus sequence typing; ST, Sequence Type; $F$, female; M, male; NT, nontypeable; P1.- = non-serosubtypeable; CSF, cerebrospinal fluid. No., Number

${ }^{1}$ Although this case was identified in 2008, the isolate was received at the National Microbiology Laboratory in January 2009 and therefore, it was included in this study

2 This case occurred in an Ontario resident but hospitalized in Manitoba and the case isolate was analyzed at the National Microbiology Laboratory by a vaccine preventable serogroup, public health management would include chemoprophylaxis and immunoprophylaxis with quadrivalent meningococcal vaccine for close contacts (11).

Five of the cases were caused by strains expressing the serotype antigen 2a with PorA genotype of P1.5,2,36-2 and typed by MLST as ST-11, a member of the ST-11 cc. Another serotype 2a MenW strain with PorA genotype of P1.5,2,36-2 was identified as ST-10826, a single locus variant (SLV) of ST-11, and therefore, also a member of the ST-11 cc. These six cases all occurred since May 2014, were in adults and four were male. Evidence that the six W:2a:P1.2,(5) ST-11 isolates were clonal included the lack of the characteristic fumC gene mutation that characterized them as ET-37 and not ET-15. None of the cases reported travel to the Hajj.

Six MenW case isolates belonged to ST-22 cc and presented as four different STs (two each of ST-22 and ST-184; and one each of ST-8230 and ST-8974). In addition, these six MenW isolates were also heterogeneous in terms of their antigenic formulas and PorA genotypes (Table 1). Five of the six (83\%) MenW isolates belonging to the ST-22 cc occurred prior to 2012 and half were young children. The remaining MenW isolate was typed as ST3705, a member of the ST-167 cc commonly associated with MenY according to the Neisseria.org MLST website (12).

\section{Discussion}

This laboratory-based surveillance report captured the emergence or re-emergence of the MenW strain expressing serotype antigen $2 \mathrm{a}$ and serosubtype antigens of $\mathrm{P} 1.2$ or P1.5,2 with PorA genotype of P1.5,2,36-2 and belonging to the ST-11 cc. This clone seems to have emerged and displaced the traditional MenW clone of W:NT:P1.6 that belonged to the ST-22 cc since May 2014 (authors' unpublished data). Through genotypic and phenotypic analysis, ST-11 MenW 2a:P1.5,2 was first identified in Canada in 1970 (13). Prior to the spring of 2000, ST-11 MenW has only caused sporadic disease. However, the first large MenW outbreak involving $>400$ cases from 16 countries due to a ST-11 cc strain was reported among the pilgrims attending the Hajj in Mecca in year $2000(13,14)$. Subsequent sporadic cases were thought to be due to pilgrims returning from the Hajj and transmitting the infection to their close contacts, as have been reported in Europe (15). This clone has since spread to sub-Saharan Africa (16) and South America $(17,18)$. However, beginning in 2010 , several countries have reported an increase in IMD due to ST-11 MenW (19-22). Unusual clinical presentation of MenW IMD due to this clone has been reported and the possibility of endemic local transmission has also been suggested $(23,24)$. The finding of six MenW cases associated with the ST-11 cc in Ontario since May 2014 was unusual, especially as none have reported any travel to the Hajj or exposure to individuals returning from the Hajj.

The majority (10 out of 13) of MenW cases in Ontario occurred in adults, particularly older adults. While all ST-11 cases occurred in adults, the ST-22 cases occurred in either very young children or adults (Table 1). This was in contrast to the findings reported from South America with most MenW:2a ST-11 cases occurring in young children. For example, in Argentina, 63\% of MenW:2a ST-11 cases were in children less than nine years old (18); in 
Chile, $47 \%$ of cases were in children less than five years old (25); while in Brazil, the average age was 15 years (26). In England and Wales, the increase in disease due to the ST-11 MenW strain was noticed in all age groups $(24,27)$. As there have been only six cases reported in Ontario, it is too early to note whether this age pattern has any epidemiological significance.

The ST-11 N. meningitidis cc has been known as a hypervirulent clone with the potential to cause epidemics. The first documentation of the ST-11 meningococci causing an epidemic was in the 1960s in the US Army $(28,29)$. ST-11 meningococci may be found in strains with serogroup antigens of $B, C, W$ and $Y(30)$. The most significant IMD event in Canada was due to an ST-11 cc MenC strain typed as ET-15, a genetic variant within the ST-11 cc of N. meningitidis (31). This clone first emerged in the province of Ontario in 1986 (31) and caused a localized outbreak in January 1989. By 1990 it had spread throughout the province. This clone was also responsible for the increase in MenC disease in the U.S., causing several outbreaks other than spreading to other provinces within Canada (32). The global spread of this ET-15 clone leading to outbreaks in multiple countries has been described (33). Although sporadic cases of ET-15 MenB have been observed in Canada (probably through capsule switching), such strains failed to establish sufficiently to cause any sustained disease in Canada (34). MenY ST-11 has not been observed in Canada (authors' unpublished observation). Although others have discussed the potential relationship between the ST-11 MenC and the ST-11 MenW through capsule switching (13), the finding of sporadic MenW (and/or MenC) ST-11 isolates as far back as 1970 has made it impossible to determine if any such capsule switching event had occurred.

The potential unusual clinical presentation due to MenW ST-11 that others have reported (23) along with possible endemic spread (24) without direct or indirect travel history (through exposure to travellers) and age range of cases reported in Ontario should alert clinicians to remain vigilant and consider a diagnosis of IMD in all age groups. This short surveillance report serves to inform the public health and clinical community of the possible emergence of a ST-11 MenW strain in Ontario, which needs to be monitored.

\section{Acknowledgements}

We thank Dennis Law, Jianwei Zhou and Saul Deng for providing laboratory assistance in the analysis of strains, and the NML's DNA Core Service for providing assistance in nucleotide sequencing. We also thank Deirdre Soares and the Public Health Ontario Laboratory Reference Identification Section staff.

\section{Conflict of interest}

None.

\section{Funding}

This publication made use of the Neisseria Multi Locus Sequence Typing website (http://pubmlst.org/neisseria/) developed by Keith Jolley and sited at the University of Oxford (Jolley \& Maiden 2010, BMC Bioinformatics, 11:595; http://bmcbioinformatics.biomedcentral.com/articl es/10.1186/1471-2105-11-595). The development of this site has been funded by the Wellcome Trust and European Union.

\section{References}

1. Rosenstein NE, Perkins BA, Stephens DS, Popovic T, Huges JM. Meningococcal disease. N Engl J Med. 2001 May; 344:1378-1388.

2. Apicella M. Neisseria meningitides. In Mandell G, Bennett JE, Dolin R, eds. Mandell, Douglas and Bennett's principles and practice of infectious diseases, $7^{\text {th }}$ edition. Philadelphia, PA: Churchill Livingstone Elsevier; 2009. p. 2737-52.

3. Harrison LH, Trotter CL, Ramsay ME. Global epidemiology of meningococcal disease. Vaccine. 2009;27S:B51-B63.

4. Varughese PV, Carter AO. Meningococcal disease in Canada, surveillance summary to 1987. Can Dis Wkly Rep. 1989;15:89-96.

5. Deeks SL, Kertesz D, Johnson W, Ashton F. Surveillance of invasive meningococcal disease in Canada, 1995-1996. Can Comm Dis Rep. 1997;23(16):121-5.

6. Li YA, Tsang R, Desai S, Deehan H. Enhanced surveillance of invasive meningococcal disease in Canada, 2006-2011. Can Comm Dis Rep. 2014;40(9):160-9.

7. Government of Canada [Internet]. Immunization schedule tool. [updated 2015 June 25; cited 2016 Sep 29]. Ottawa: Government of Canada; 2015. Available from: http:// healthycanadians.gc.ca/apps/schedule-calendrier/index-eng. php.

8. Government of Ontario [Internet]. The Integrated Public Health Information System of Public Health Ontario. Ottawa: Public Health Ontario; 2014. Available from: http://www. health.gov.on.ca/en/pro/programs/publichealth/oph_ standards/docs/meningococcal_cd.pdf.

9. Jamieson FB, Rawte P, Deeks SL, Zhou J, Law DKS, Deng $S$, et al. Genetic and antigenic characterization of invasive endemic seroroup B Neisseria meningitidis from Ontario, Canada, in 2001-2010. J Med Microbiol. 2013;62:46-55.

10. Vogel U, Claus H, Frosch M. Molecular basis for distinction of the ET-15 clone within the ET-37 complex of Neisseria meningitidis. J Clin Microbiol. 2000;38:941-2.

11. Government of Ontario. Ministry of Health and Long-Term Care [Internet]. Infectious diseases protocol, 2014. Appendix A: Disease specific chapters. Chapter: Meningococcal disease, invasive. [updated 2014 Jan; cited 2016 Sep 29]. Toronto, ON: Queen's Printer for Ontario; 2015. Available from: http://www.health.gov.on.ca/en/pro/programs/ publichealth/oph_standards/docs/meningococcal_chapter. pdf. 
12. PubMLST [Internet]. Neisseria sequence typing home page. [cited 2016 Sep 29]. Available from: http://pubmlst.org/ neisseria/.

13. Mayer LW, Reeves MW, Al-Hamdan N, Sacchi CT, Taha MK, Ajelllo GW, et al. Outbreak of W135 meningococcal disease in 2000: Not emergence of a new W135 strain but clonal expansion within the electrophoretic type -37 complex. J Infect Dis. 2002 June; 185:1596-1605.

14. Taha MK, Achtman M, Alonso JM, Greenwood B, Ramsay M, Fox A, et al. Serogroup W135 meningococcal disease in Hajj pilgrims. Lancet. 2000 Dec;356(9248):2159.

15. Aguilera JF, Perrocheau A, Meffre C, Hahne S and the W135 Working Group. Outbreak of serogroup W135 meningococcal disease after the Hajj pilgrimage, Europe, 2000. Emerg Infect Dis. 2002 Aug;8(8):761-767.

16. du Chatelet IP, Traore Y, Gessner BD, Antignac A, Naccro $B$, Njanpop-Lafourcade BM, et al. Bacterial meningitis in Burkina Faso: Surveillance using field-based polymerase chain reaction testing. Clin Infect Dis. 2005 Jan;40:17-25.

17. Weidlich L, Baethgen LF, Mayer LW, Moraes C, Klein CC, Nunes LS, et al. High prevalence of Neisseria meningitidis hypervirulent lineages and emergence of W135:P1.5,2:ST-11 clone in Southern Brazil. J Infect. 2008;57:324-31.

18. Efron AM, Salcedo C, Regueira M, Vazquez JA. W135 invasive meningococcal strains spreading in South America: Significant increase in incidence rate in Argentina. J Clin Microbiol. 2009 Jun;47(6):1979-80.

19. Collard JM, Maman Z, Yacouba H, Djibo S, Nicolas P, Jusot, JF, et al. Increase in Neisseria meningitidis serogroup W135, Niger, 2012. Emerg Infect Dis. 2010 Sep;16(9):1496-8.

20. Hossain MJ, Roca A, Mackenzie GA, Jasseh M, Hossain MI, Muhammad S, et al. Serogroup W135 meningococcal disease, The Gambia, 2012. Emerg Infect Dis. 2013 Sep;19(9):1507-10.

21. Zhou H, Liu W, Xu L, Deng L, Deng Q, Zhuo J, et al. Spread of Neisseria meningitidis serogroup W clone, China. Emerg Infect Dis. 2013 Sep;19(9):1496-9.

22. Hu S, Zhang W, Li F, Hu Z, Ma E, Zheng T, et al. Neisseria meningitidis serogroup W135 sequence type 11, Anhui Province, China, 2011-2013. Emerg Infect Dis. 2014 Jul;20(7):1236-8.

23. Vienne P, Ducos-Galand M, Guiyoule A, Pires R, Giorgini $D$, Taha MK, et al. The role of particular strains of Neisseria meningitidis in meningococcal arthritis, pericarditis, and pneumonia. Clin Infect Dis. 2003 Dec;37:1639-42.
24. Ladhani SN, Beebeejaun K, Lucidarme J, Campbell H, Gray S, Kaczmarski E, et al. Increase in endemic Neisseria meningitidis capsular group W sequence type 11 complex associated with severe invasive disease in England and Wales. Clin Infect Dis. 2015;578-85.

25. Valenzuela MT, Moreno G, Vaquero A, et al. Emergence of W135 meningococcal serogroup in Chile during 2012 [in Spanish]. Rev Med Chile. 2013;141 959-67.

26. Barroso DE, Castineires TMPP, Cabral AC, Vicente ACP, Robelo MC, Cerqueira EO, Tulenkoo MM, Marsh JW, Krauland MG, Harrison LH. Neisseria meningitidis ST-11 clonal complex bearing capsule serogroups $B, C$, or $W$ in Brazil. J Infection. 2013 Jun;(6):547-50.

27. Bethea J, Makki S, Gray S, MacGregor V, Ladhani S. Clinical characteristics and public health management of invasive meningococcal group W disease in the East Midlands region of England, United Kingdom, 2011 to 2013. EuroSurveillance. 2016 Jun;21(24).

28. Brundage JF, Zollinger WD. Evolution of meningococcal disease: Epidemiology in the US Army. In Vedros NA (ed). Evolution of meningococcal disease. Boca Raton, FL: CRC Press Inc.; 1987. Vol. 1, p. 99-119.

29. Wang JF, Caugant DA, Morelli G, Koumare B, Achtman $M$. Antigenic and epidemiologic properties of the ET37 complex of Neisseria meningitidis. J Infect Dis. 1993 Jun;167:1320-9.

30. Caugant DA. Population genetics and molecular epidemiology of Neisseria meningitidis. APMIS. 1998; 106:505-25.

31. Ashton F, Ryan JA, Borczyk A, Caugant DA, Mancino $L$, Huang $D$, et al. Emergence of a virulent clone of Neisseria meningitidis serotype $2 a$ that is associated with meningococcal group C disease in Canada. J Clin Microbiol. 1991 Nov;29(11):2489-93.

32. Jackson LA, Schuchat A, Reeves MW, Wenger JD. Serogroup $C$ meningococcal outbreaks in the United States. An emerging threat. JAMA. 1995 Feb;273(5):383-9.

33. Jelfs J, Munro R, Ashton FE, Caugant DA. Genetic characterization of a new variant within the ET-37 complex of Neisseria meningitidis associated with outbreaks in various parts of the world. Epidemiol Infect. 2000;125:285-98.

34. Kertesz DA, Coulthart MB, Ryan JA, Johnson WM, Ashton FE. Serogroup B electrophoretic type 15 Neisseria meningitidis in Canada. J Infect Dis. 1998 Jun;177(6):1754-7. 